Научная статья

УДК 81

DOI $10.18101 / 2686-7095-2021-3-112-116$

\title{
ДИАЛЕКТНЫЕ ЭКСПРЕССИВЫ, ХАРАКТЕРИЗУЮЩИЕ КРЕСТЬЯНИНА В ЕГО ОТНОШЕНИИ К ТРУДУ И ХОЗЯЙСТВУ В АРХАНГЕЛЬСКОЙ ОБЛАСТИ
}

\author{
(C) Юдина Татьяна Михайловна \\ кандидат филологических наук, доцент, \\ Институт филологии и межкультурной коммуникации, \\ Северный (Арктический) федеральный университет им. М. В. Ломоносова \\ Россия, 163001, г. Архангельск, наб. Северной Двины, 17, корп. 1 \\ t.yudina@narfu.ru
}

\begin{abstract}
Аннотация. В статье отражена группа севернорусских диалектов, характеризующих крестьянина в его отношении к труду и хозяйству. Аксиологическая оценка диалектоносителей освещает отношение северного народа к труду. Рассматриваются такие тематические группы слов, как 'характеристика человека в его отношении к имуществу', 'характеристика нечестного человека'. В рамках этих групп выделяются лексико-семантические группы 'жадный человек, скупец', 'ветреный, беспутный, беспечный человек’, ‘двуличный, лицемерный, пронырливый хитрец, пройдоха, плут'.

По диалектным словарям автор выявляет инвентарь и семантику слов, по дефинициям фиксирует особенности видения картины мира диалектоносителей Севера. Аксиологическая характеристика позволяет выявить и дать общую оценку трудоспособности человека. Зафиксировано множество пейоративных лексем: наименования ленивых, бесхозяйственных, беспечных и безответственных людей, не думающих о своем проживании и благосостоянии.
\end{abstract}

Ключевые слова: аксиология, диалекты, диалектные словари, Архангельская область, Русский Север, семантика, жизнедеятельность.

\section{Для цитирования}

Юдина T. М. Диалектные экспрессивы, характеризующие крестьянина в его отношении к труду и хозяйству в Архангельской области // Вестник Бурятского государственного университета. Филология. 2021. Вып. 3. С. 112-116.

Исторические данные языкознания, лексикологии, диалектологии необходимы для познания национальной культуры. Диалекты с экспрессивной оценочной семантикой характеризуют менталитет и картину мира каждого народа. В диалектных словах народ оценил качество уровня жизни конкретного человека, которое зависит от работоспособности человека, определяет его возможности воспроизводить блага. Актуальность темы несомненна: от отношения к труду зависел уровень благосостояния крестьянской семьи, благополучие, здоровье и жизнь семьи в целом.

«Диалекты с аксиологической семантикой - этнокультурная информация о менталитете диалектоносителей, отражает исторические основы народа» [Юдина, 2020 , с. 752]. Аксиологическая семантика отражает этнокультуру диалектоносителей.

Цель статьи - представить тематические группы (ТГ) с лексикосемантическими подгруппами (ЛСГ) диалектов с коннотативной характеристикой 
T. М. Юдина. Диалектные экспрессивы, характеризующие крестьянина в его отношении к труду и хозяйству в Архангельской области

«названия человека по отношению к труду» в говорах Архангельской области. По региональным диалектным словарям автор выявляет инвентарь диалектных лексикосемантических групп (ЛСГ) конкретной семантики, по дефинициям моделирует картину мира диалектоносителей Севера.

Источники: данные «Архангельского областного словаря» - сокращенно в тексте: АОС [1], «Словаря говоров Русского Севера»: СГРС [3], «Словаря русских говоров Карелии»: СРГК [4], «Словаря русских народных говоров»: СРНГ [5], «Словаря областного архангельского наречия в его бытовом и этнографическом применении» А. О. Подвысоцкого: Подвыс [2].

Ф. П. Сороколетов отмечал, что «семантическая разработка слов, грамматическая характеристика и цитатный материал, иллюстрирующий особенности функционирования слова в живом народном говоре, делают словари источниками изучения русской диалектной лексики. Словари - единственный вид систематизированных собраний диалектных лексических материалов» [Сороколетов, 1968, с. 12].

Аксиологичность (оценочность) - это одобрительная или неодобрительная (пейоративная) оценка, заключенная в значении слова. «Общенародные слова известны на территории Архангельской области и зафиксированы в толковых словарях без территориальных помет, а диалектные известны на территории Архангельской области, но не зафиксированы в словарях или зафиксированы с пометой 'обл.'» [Юдина, 2020, с. 752].

ТГ 'Характеристика человека в его отношении к труду и хозяйству'.

1. ЛСГ № 1 'человек ленивый’: апостол [Котл. Арх., СГРС, 1, 19], балахрыст [Вель, Кон., Шенк., Холм., Пин. Арх., АОС, 1, 101], балахлыста [Холм., Онеж. Арх., АОC, 1, 101], балахрыстка [Холм. Арх., АОС, 1, 102], барун [Шенк. Арх., АОС, 1, 115], барынок [Мез. Арх., АОС, 1, 115], безделка [Онеж. Арх., АОС, 1, 147], безделюга [Пин. Арх., АОС, 1, 147], балатряс [Холм. Арх., АОС, 1, 101], бобель [Лен., Пин., Прим. Арх., АОС, 2, 38], болтун [Арх., СРНГ, 3, 82], бурлак [Пин., Леш., Онеж. Арх., АОС, 2, 181], валявка [Арх., СРНГ, 4, 35], ведило [Леш. Арх., АОС, 3, 75], гоголь [Карг. Арх., АОС, 9, 186], гольеба [Леш. Арх., АОС, 9, 284], даровик [Пин. Арх., АОС, 10, 265], доптеха [Пин. Арх., АОС, 11, 451], дошник [Пин. Арх., AOC, 12, 215], дрыгало [Онеж. Арх., АОС, 12, 319], дрын [Леш., Мез. Арх., АОС, 12, 321-322], дубак [Леш., Плес. Арх., АОС, 12, 330], дуботолок [Леш., Вил., Пин. Арх., АОС , 12, 335], дулупес [Онеж. Арх., АОС, 12, 348], дыдло [Вил., Холм., Прим. Арх., АOC, 12, 432-433], лентяк [Сев. Дв. Арх., СРНГ, 16, 357], неработь [Шенк. Арх., АОС, 21, 137], одер (одра) [Арх., СРНГ, 23, 15] окаем, окоем [Арх., СРНГ, 23, 106], отеть [Арх., СРНГ, 24, 179].

2. ЛСГ № 2 ‘человек трудолюбивый/ работающий хорошо и быстро’: аред [карг. Арх., СРНГ, 1, 21], воротило [Леш., Кон., Карг. Арх., АОС, 5, 104], гоношун [Пин. Арх., АОС, 9, 309], добруха [Мез. Арх., АОС, 11, 206].

3. ЛСГ № 3 'человек неумелый, делающий все небрежно, наспех, плохо / нерадивый/’: беспоряха [Усть., В.-Т., Шенк., Холм., Вин., Вил., Красн., Пин., Онеж, Плес., Кон. Арх., АОС, 2, 15], ворона [Пин., Карг., Шенк., Котл., Красн., Холм., Кон. Арх., АОС, 5, 95], воронка [Пин. Арх., АОС, 5, 98], ничевуха (ничеуха, нечевуха, нечеуха) [Арх., СРНГ, 21, 244].

4. ЛСГ № 4 'человек умелый, делающий все отлично / мастер': делальщица [Вин. Арх., АОС, 10, 430], дельница [Онеж. Арх., АОС, 11, 16], деловщица [Мез. Арх., AOC, 11, 14], дельщица [Онеж. Арх., АОС, 11, 16], обряжуха [Арх., СРНГ, 22, 226].

5. ЛСГ № 5. ‘бесхозяйственный, недомовитый человек’: бездомовик [Вил. Арх., АОС. 1, 148], бездомовица [Вил. Арх., АОС. 1, 148], бездомовка [Вил. Арх., АОС. 1, 
148], бездомовник [Вил. Арх., АОС, 1, 148], беспелюга [Пин., Онеж. Арх., АОС, 13], беспоряха [Усть., В.-Т., Шенк., Холм., Вин., Вил., Красн., Пин., Онеж, Плес., Кон. Аpх., АOC, 2, 15], бобылка [Мез., Вин., Кон., Карп.. Вель., Холм., Леш., Онеж. Арх.. АОC, 2, 41], бобыль [Холм., Кон., Красн.. Шенк., Карг., Нянд., Лен., Мез., Леш., Онеж. Арх., АОС, 2, 41], овыденник [Мез. Арх., СРНГ, 22, 308].

ТГ 'Характеристика человека в его отношении к имуществу'

1. ЛСГ 'жадный человек, скупец': барачиха [Леш. Арх., АОС, 1, 112], жад [Сев.Двин. Арх., СРНГ, 9, 57], жадник [Онеж. Арх., СРГК, 2, 31], жадуля [Онеж., Карг. Арх., СРГК, 2, 32], жидок [В.-Т. Арх., СГРС, 3, 368], жом [Сольвыч. Арх., СРНГ, 9, 215], загребало [Арх., СРНГ, 10, 28].

2. ЛСГ 'ветреный, беспутный, беспечный человек': ветреница [Карг. Арх., АОС, 4, 21], овыдельник [Мез. Арх., СРНГ, 22, 308], овыденник [Мез. Арх., СРНГ, 22, 308], одновыденка [Арх., СРНГ, 23, 38], одновыденок [Арх., СРНГ, 23, 38]. барачиха, -и, ж. скупая женщина.

ТГ 'Характеристика нечестного человека'

ЛСГ 'двуличный, лицемерный, пронырливый хитрец, пройдоха, плут': блудень [Вил. Арх., АОС, 2, 35], вывертка [Вин. Арх., АОС, 6, 31], мутовка [Холм. Арх., АОС , 19, 30], приманило [Арх., СРНГ, 31, 235].

Далее в словнике представляем семантику некоторых экспрессивных лексем и лексико-семантических вариантов, зафиксированных в словарях.

Апостол - 'бездельник, разгильдяй'; аред — 'очень трудолюбивый, жадный на работу человек'; аредовка - жен. к аред (в 1 значении); балатряс, - $a$, м. - 'никчемный человек, бездельник, лоботряс, пустозвон'; балахлыста, -и, ж. - 'бездельница, лентяйка'; балахрыст, -a, м. - 'никчемный человек, бездельник, лоботряс, пустозвон'; балахрыст$\kappa a,-u$, ж. - женск. к балахрыст ; баляса, -и, ж. и м. - 'никчемный человек, бездельник, лоботряс, пустозвон'; бара, -bl, ж. — ‘избалованная, любящая безделье, в достатке живущая женщина'; бараболка, -и, ж. - 'никчемный человек, бездельник, лоботряс, пустозвон'; барабоша, -и, ж. и м. - 'никчемный человек, бездельник, лоботряс, пустозвон'; барабуша, -ыl, ж. и м. - 'никчемный человек, бездельник, лоботряс, пустозвон'; барахло, $-a$, ср. - 'никчемный человек, бездельник, лоботряс, пустозвон'; барахольщик, - $a$, м. никчемный человек, бездельник, лоботряс, пустозвон'; барун, - $a$, м. - 'бездельник, барин'; барынок, -нка, м. - 'лентяй, бездельник' безделка, -и, ж. - 'лентяйка'; безделюга, -и, м. и ж. - 'бездельник, лентяй'; бездомовик, - $а$, м. - 'бесхозяйственный человек'; бездомовииа, -ыl, ж. - ж. к бездомовик'; бездомовка, -и. ж. - 'бесхозяйственная женщина'; бобель, -я, м. - лентяй, нерасторопный человек'; болтун, - $a$, м. - 'лентяй, гуляка'; брянка, -и, ж. и м. - 'пустомеля, много болтающий и не любящий работать человек'; бурлак, - $a$. м. - ‘лентяй, бездельник и барин'; валявка, -и, м. и ж. - 'ленивый человек, лентяй, лентяйка'; ворона, -bl, ж. и м. - 'разиня, неумелый, нерасторопный человек'; воронка, -и, ж. - 'разиня, неумелый, нерасторопный человек'; воротило, - $a$, м. 'инициативный, деловой человек'; гоголь, -я, им. мн. гоголи и гоголя, - 'ленивый человек, лентяй'; гоношун, - $a$, м. - 'суетливый человек'; даровик, - $a$, м. - 'не занятый работой человек, бездельник'; делальщица, -и, ж. - 'умелая женщина, мастерица, работница'; деловщица, -bl, ж. - 'умелая, искусная женщина'; дельнииа, -и, ж. - 'умелая, искусная женщина'; дельщица, -bl, ж. - 'умелая, искусная женщина'; добруха, -u, ж. 'трудолюбивая женщина'; доптеха, -и, ж. и м. - 'лентяк, недотепа'; дошник, -a, м. 'здоровый, крепкий, но ленивый человек, лоботряс'; дрыгало, - $a$, ср. - 'бездельник, лоботряс'; дрын, - $a$, м. - 'бездельник, лоботряс, пустозвон'; дубак, -a, м. - 'великовозрастной ленивый человек, лоботряс'; дулупес, - $a$, м. - 'бездельник, лентяй'; дыдло, - $a$, ср. - 'великовозрастной ленивый человек, лоботряс'; зырян, -а, м. - 'слоняющийся без дела, лентяй'; лентяк, - $а$, м. - ленивый человек'; неработь, -и, м. и ж. - 'лентяй, лени- 
T. М. Юдина. Диалектные экспрессивы, характеризующие крестьянина в его отношении к труду и хозяйству в Архангельской области

вый человек'; ничевуха, ничеуха, нечевуха и нечеуха, -и, м. и ж. - 'человек, который ничего не умеет и не хочет делать'; обряжуха, -и, ж. - 'хорошая, домовитая хозяйка'; овыдельник, - $а$, м. - 'беспечный, беззаботный человек, думающий только о сегодняшнем дне'; овыденник, - $a$, м. - 'беспечный, беззаботный человек, думающий только о сегодняшнем дне'; одновыденка, ж. - жен. к одновыденок’; одновыденок, м. - 'человек, имеющий склонность жить одним днем, расходовать все за один день, расточительный, небережливый человек'; окаем, окоем, -а. м. - ‘лентяй, тунеядец'и др.

Как видно, слов с положительной семантикой намного меньше (быть трудолюбивым и хозяйственным - это норма, так и должно быть, с точки зрения крестьянина, вообще не надо оценивать). Экспрессивные единицы со значением характеристики человека в говорах Архангельской области оценивают человека с позиций нормы: мы видим положительную оценку трудолюбивых людей. Русский народ ценил силу, здоровье и способность человека много работать и, как следствие, жить в достатке. Слов с негативной оценкой намного больше: отсутствие трудолюбия - это отступление от нормы жизни крестьянина и поэтому порицается. Зафиксировано множество пейоративных лексем: наименования ленивых, бесхозяйственных, беспечных и безответственных людей, не думающих о своем проживании и благосостоянии.

В формировании общей картины мира участвуют в комплексе объективный, мыслительный и языковой инвертарно-таксономический, системный блоки информативности. Экспрессивные слова позволяют выявить оценку народа относительно внутреннего мира человека, его внешнего облика и здоровья, трудолюбия и работоспособности. Диалектная лексика отражает видение мира коренным народом Русского Севера: культуру северной провинции России, сформировавшиеся на протяжении столетий идеалы и ценности народа. Исследование экспрессивов разных ТГ в говорах Севера по-прежнему перспективно.

\section{Литература}

1. Архангельский областной словарь: в 13 т. / под редакцией О. Г. Гецовой. Москва: Изд-во МГУ, 1980-2010. Текст: непосредственный.

2. Подвысоцкий А. О. Словарь областного архангельского наречия в его бытовом и этнографическом применении. Москва, 2008. 576 с. Текст: непосредственный.

3. Словарь говоров Русского Севера: в 4 т. / под редакцией А. К. Матвеева. Екатеринбург, 2001-2009. Текст: непосредственный.

4. Словарь русских говоров Карелии и сопредельных областей: в 6 т. / главный редактор А. С. Герд. Санкт-Петербург: Изд-во Санкт-Петербургского ун-та, 1994-2005. Текст: непосредственный.

5. Словарь русских народных говоров: в 50 т. Санкт-Петербург: Наука. 1965-2020. Текст: непосредственный.

6. Сороколетов Ф. П. Диалектная лексика в ее отношении к словарному составу общенародного языка // Слово в русских народных говорах. Ленинград: Наука. Ленингр. отд-ние, 1968. С. 222-236. Текст: непосредственный.

7. Юдина Т. М. Аксиолого-вербальная характеристика человека по внешнему виду в современных севернорусских диалектах // Глобальные проблемы Арктики и Антарктики: сборник научных материалов всероссийской конференции с международным участием, посвященной 90-летию со дня рождения академика Николая Павловича Лаверова / отв. ред. А. О. Глико, А. А. Барях, К. В. Лобанов, И. Н. Болотов. Архангельск, 2020. С. 752-755. Текст: непосредственный.

Статья поступила в редакцию 19.09.2021; одобрена после рецензирования 15.10.2021; принята к публикации 29.10.2021. 


\section{DIALECTAL WORDS WITH EXPRESSIVE MEANING CHARACTERIZING PEASANTS' ATTITUDE TO LABOUR AND ECONOMY IN ARKHANGELSK OBLAST}

\section{Tatyana M. Yudina}

Cand. Sci. (Phil.), A/Prof. of Russian Language and Speech Culture Department, Institute of Philology and Intercultural Communication

Lomonosov Northern (Arctic) Federal University

17/1 Severnoy Dviny Emb., Arkhangelsk 163001, Russia

t.yudina@narfu.ru

Abstract. The article reflects a group of northern Russian dialects characterizing peasants' attitude to labour and economy. An axiological assessment of dialect speakers describes the attitude of the northern people to work. The article considers such thematic groups of words as 'Characteristics of a person in his relation to property', 'Characteristics of a dishonest person'. Within these groups the following lexical and semantic groups are distinguished: 'a greedy person, a miser', 'a windy, dissolute, careless person', 'a two-faced, hypocritical, sneaky dodger, sharker, rogue'. Using dialect dictionaries, we have identified the inventory and semantics of words, and described the peculiarities of the world view of northern dialect speakers though the definitions. The axiological characteristics allows identifying a person's ability to work. We have recorded many pejorative lexemes: naming units for lazy, mismanaged, careless and irresponsible people who do not think about their living and welfare. Keywords: axiology, dialects, dialect dictionaries, Arkhangelsk Oblast, Russian North, semantics, life-activity.

For citation

Yudina T. M. Dialectal Words with Expressive Meaning Characterizing Peasants' Attitude to Labour and Economy in Arkhangelsk Oblast. Bulletin of Buryat State University. Philology. 2021; 3: 112-116 (In Russ.).

The article was submitted 19.09.2021; approved after reviewing 15.10.2021; accepted for publication 29.10.2021. 